\title{
Vengeance, Variously: Revenge Before Kyd in Early Elizabethan Drama
}

In 1973, Ronald Broude observed that, though 'revenge tragedy ranks among the major dramatic forms left us by the English Renaissance, we know relatively little about its development prior to its remarkable vogue in the 1580 s and ' $90 \mathrm{~s}^{\prime} .{ }^{1}$ In his subsequent investigation, Broude suggests that a search for antecedents to the Elizabethan revenge play might first consider the larger 'trends in religion and politics' that marked the contemporary cultural scene - a rich milieu that gave rise to certain 'forerunners' of the genre, such as the morality plays of the mid-sixteenth-century. Of course, in the decades following the publication of Broude's essay, scholars have greatly sharpened our sensitivity to this larger cultural context of revenge, and recent work on revenge tragedy — such as Thomas Rist's Revenge Tragedy and the Drama of Commemoration in Reforming England (2008), the latest full-length treatment of the genre - has demonstrated how the classic Elizabethan revenge play is imbricated with a complex series of ideological and ritualistic investments. ${ }^{2}$ But despite this renewed (and very welcome) contextual focus, there remains a more general sense in which the thrust of Broude's remark remains fundamentally unanswered: we have yet to produce a full account of literary revenge on the early Elizabethan stage, before the flowering of revenge tragedy proper in the century's final decades.

Accordingly, this essay will respond to Broude's call for 'a systematic study of revenge tragedy's dramatic antecedents in England'. While the development and maturation of revenge tragedy has long been a locus of scholarly inquiry, the opposite is true of the genre's precursors: apart from scattered treatments of Senecanism, there has been little sustained discussion of how revenge fared as a theme in English plays before the advent of Thomas Kyd's The Spanish Tragedy and before revenge tragedy became a recognizable dramatic archetype. ${ }^{3}$ This essay will amend this lacuna by examining revenge as it appears in the surviving corpus of pre-Kydian Elizabethan drama. With 
Broude, I am convinced that such an investigation must indeed be systematic: the ubiquity of the theme, I suggest, is only appreciated by means of accumulation and aggregation, rather than by the local elaboration of certain representative plays. ${ }^{4}$ When looking at the period's drama from this bird's eye view, we may best apprehend that revenge enjoyed a surprisingly vibrant career on the English stage, well before the popularization of what is now called revenge tragedy. Before revenge came to inhabit its own generic space, it functioned as a widely versatile thematic and dramaturgical element in countless plays, ranging from raucous comedies to stately classical histories. Such plays, to be sure, are distinctly not revenge drama in the vein of The Spanish Tragedy: instead, they attest to the viability and prevalence of the theme in the corpus of earlier Elizabethan theatre, before revenge tragedy assumed anything like a structural form. A survey of revenge in such plays does not diminish the scope of Kyd's innovation, but rather allows us to contextualize it more fully. With The Spanish Tragedy, Kyd intensified and systematized structurally a theme that had for decades already been a well-worn mainstay on the English stage.

Why is it necessary to excavate the dramatic prehistory of the revenge play? Such investigation, I suggest, forces us to revise our account of the genre's origins, and elucidates its larger place within the Elizabethan dramatic tradition. There is no question that The Spanish Tragedy inaugurates the genre of revenge tragedy as it is now understood: as has been well-documented, Kyd's remarkable play set the thematic, structural, and tropological agenda that would be redeployed (and reimagined) in the corpus of 'classic' revenge tragedies. ${ }^{5}$ But to understand the true nature of Kyd's achievement, and to contextualize this development of revenge tragedy as a systematized genre, we must first interrogate the broader workings of revenge in early Elizabethan theatre, to account for the local dramatic heritage from which The Spanish Tragedy (and its heirs) emerged. As will become clear, revenge was a robust category of both serious and casual interest to the early Elizabethan dramatists, well before anything like the genre of revenge tragedy existed. In The Spanish Tragedy, Kyd funneled, and subsequently concentrated, a thematic energy that had already soaked, with various intensity, into the far corners of contemporary drama. As scholars continue to revise our understanding of revenge tragedy, this deep dramatic context requires more direct recognition.

Before proceeding, I must begin with a caveat about the scope of the project. As stated above, this essay surveys the prominence of dramatic revenge in Elizabethan plays that predate The Spanish Tragedy, with hope that the 
evidence amassed will contribute to our continually evolving sense of revenge's literary and cultural significance in early modern England. To establish a canon of pre-Kydian plays, however, is no easy task: the composition date of The Spanish Tragedy is a famous critical crux, and the estimates of current Kyd scholars range anywhere from 1587 to $1592 .{ }^{6}$ For the sake of inclusiveness, I use 1592 as the terminal date for my survey - though The Spanish Tragedy (and likely Titus Andronicus) had almost certainly been staged by that time. ${ }^{7}$ My aim, it follows, is not to quibble about whether a particular play predated The Spanish Tragedy, but instead to establish more generally that vengeance had a rich dramatic life well before revenge drama (as understood today) came to exist as an easily identifiable, systematized genre in the final years of Elizabeth's reign. $^{8}$

Furthermore, I have been equally liberal in my identification of revenge motifs and themes. Well before the Kydian revenge play blossomed into a genuine dramatic type, playwrights variously embraced the theatrical potential of revenge, with equally various levels of commitment and interest: in some plays, revenge is essential to an overall thematic and atmospheric agenda, while in others, it is a casual anomaly, deployed only to punctuate a particular dramatic moment or episode. In the second case, I contend that these incidental occurrences are a crucial contour of the early revenge tradition, and I have thus included such examples alongside plays that more thoroughly explore the revenge theme. Revenge takes on a variety of shapes in these early plays. Manifestations range from the terrifying vengeance of Protestant interludes to the laughable threats of the era's comic villains. As I hope to show, such contextual flexibility is a key feature of revenge on the early Elizabethan stage, and it forms a key piece of the dramatic milieu from which revenge tragedy proper would eventually develop.

A survey of early dramatic revenge, of course, must begin with Seneca. Seneca's influence on early Elizabethan theatre (and on revenge tragedy in particular) is a complex, well-studied topic, but the basic narrative is familiar enough: translations of Seneca in the 1560s demonstrated the thematic and atmospheric potential of dramatic revenge, even if the bloodshed and horror attached to his name did not become a regular on-stage feature until decades later. ${ }^{9}$ Led by the poet and classicist Jasper Hayward, whose Troas (1559), Thyestes (1560), and Hercules Furens (1561) provided the impetus, university students translated Seneca's extant drama throughout the rest of the 1560s; their individual editions were published almost immediately as single volumes, before being collected by Thomas Newton in Seneca His Tenne 
Tragedies (1581). Importantly for the subsequent history of dramatic revenge, these early translators routinely emphasized and extended the more horrific elements of their Latin originals. In Troas, for example, Heywood invents a scene in which Achilles' ghost demands revenge, while in his Thyestes he adds a blood-chilling soliloquy rich with 'grisly images of Hell and details of the punishment he demands for Atreus'. ${ }^{10}$ Such additions set a tone that would quickly migrate throughout the period's drama.

At the same time that university men were translating Seneca, the gentlemen of the Inns of Court sponsored the first great burst of Elizabethan tragedy. Though these plays show little affinity with the popular Senecanism of the 1590s, they were self-consciously modeled on Senecan form, and they accordingly provide ample evidence of revenge themes on the mid-century Tudor stage. Norton and Sackville's Gorboduc (1561), the first English blank verse tragedy, maps a revenge motif onto a family struggle of royal inheritance: Ferrex, the slighted brother, claims that 'Such causeless wrong and so unjust despite / May have redress or, at the least, revenge' (1.1.12-13), and later, his mother Videna vows that 'here in earth this hand shall take revenge' for Ferrex's murder - a promise she fulfills by slaying her fratricidal son Porrex (4.1.34). ${ }^{11}$ Similarly, in 1566 George Gascoigne (with Francis Kinwelmersh) translated Ludovico Dolce's Italian play Giocasta (1549), itself a translation of a Latinized version of Euripides's Phoenician Women; their English Jocasta explores (among other things) a minor revenge theme in the Oedipus cycle. As in Gorboduc, familial usurpation spurs the conflict: finding his brother unwilling to yield the rule of Thebes, Pollinyces vows that his 'life shall not be lefte without revenge' (2.1.11). ${ }^{12}$

Soon after, in 1567 five authors each contributed an act to Gismond of Salerne, the first English tragedy to be based on an Italian novella. More importantly, it is also one of the first Elizabethan plays that can be rightly said to treat the passion of revenge as a central theme. Drawn from The Decameron's first story of the fourth day, Gismond portrays the vengeance of King Tancred, enraged by his daughter's decision to take a lover against his will. Unsurprisingly, the play relies on a variety of Senecan revenge conventions. It opens with the ghost-like descent of Cupid, who eagerly describes the havoc he will cause; it later stages another demon, who raises 'Vengeance and blood out of the depest helles' (4.1.1); and it gives ample time to the manic ravings of Tancred, who strives 'to work some due reuēge to fede these wretched eyes' (4.2.82). ${ }^{13}$ But perhaps most obviously, Gismond of Salerne unflinchingly 
engages the most horrific qualities of Senecan rhetoric, as a representative passage shows:

\author{
The warme entrails were toren out of his brest \\ $\mathrm{w}^{\text {th }}$ in their handes trēbling not fully dead: \\ his veines smoked: his bowelles all to strest \\ ruthelesse were rent, and throwen amidde the place: \\ all clottered lay the blood in lompes of gore, \\ sprent on his corps, and on his palëd face. \\ His hart panting out from his brest they tore, \\ and cruelly vpon a swordës point \\ they fixe the same, in this woful wise \\ vnto the King this hart do they present, \\ a sight longed for to fede his irefull eyes.
}

Though such horrors were unstaged, it's not difficult to see how the gruesome imagery, combined with the emergent revenge theme, anticipates the concerns of later revenge tragedy.

But revenge in the 1560 s was not limited to such tragic contexts: it also appears, in more minor forms, throughout the period's comedies and tragicomedies. In Gascoigne's Supposes (1566), an adaptation of Ariosto's comedy I Suppositi, the blocking-figure Damon is appalled to learn of his daughter's relationship with the servant Dulippo (a Sicilian nobleman in disguise): 'how', he wonders, 'shall I be revenged of this extreme despite... . My daughter is defloured and I utterly dishonested' $(3.3 .22,31-2) .{ }^{14}$ Similarly, in the friendship tragicomedy Damon and Pithias (c. 1565), 'Jupiter, of all wrongs the revenger' is implored to 'send down [his] hot consuming fire' and purge the tyrannical reign of King Dionysus (29). ${ }^{15}$ A revenge theme also underpins the action of the comic romance Clyomon and Clamydes (c. 1570-90, with the extent of Queen's Men authorship uncertain): after losing his promised knighthood to crafty rival Clyomon, Clamydes spends the rest of the playing pursuing his vow 'no day nor night to rest / From toylsome travell, till I have revengd my cause aright' (11. 339-40). ${ }^{16}$

Finally, revenge is integral to several of the mid-century's moral interludes. Among these, the most important is John Pikering's A new eenterlude of vice conteyninge, the historye of Horestes with the cruell reuengment of his fathers death, vpon his one naturill mother (1567) - a work that has been called 'the first revenge play of the English renaissance'. ${ }^{17}$ As the title suggests, Horestes 
foregrounds the revenge motif in the Orestes/Clytemnestra saga, but while doing so, it invests much of the play's dramatic interest in the ambiguous Vice figure. ${ }^{18}$ The Vice plays both the roles of 'Courrage' — with which Orestes has been divinely-appointed 'to reveng [his] fathers death' (1. 195) — and of amoral 'Revenge' - the force sent 'a begginge, a begginge' for any master who will have him (1045). ${ }^{19}$ Of related interest is Preston's transitional morality Cambises (1561), perhaps best remembered today through Falstaff's lampoon in 1 Henry $I V$. Though it contains only a minor revenge theme, it nonetheless marks an important movement from the descriptive horrors of early Senecanism to the bloody stagecraft of revenge tragedy proper: the play stages a flaying, a heart-rending, and (anticipating the conclusion of The Atheist's Tragedy) King Cambises' accidental, self-inflicted sword wound.

\section{Comic Revenge}

With the increase of dramatic production in the late 1570s, it was not long before revenge motifs had become integrated into virtually every genre of Elizabethan theatre. In fact, the playwrights of the 1580s found revenge to be a remarkably versatile comic theme, and a remarkable number of the era's comedies invoke revenge for either narrative or dramatic effect. ${ }^{20}$ These instances of comic revenge are not the kind of explicit parody of revenge tragedy that would later appear in such plays as A Warning for Fair Women (1596-1600) or Eastward Ho (1605). ${ }^{21}$ Instead, they demonstrate the extent to which the language and sentiment of revenge could activate genuinely comic action.

Revenge themes are integral to the earliest comedies of the 1580s. The spirit of revenge is native to the pastoral world of Peele's The Arraignment of Paris (1581-4), in which the moral Paris falls into the unenviable task of judging a divine pageant. Unsurprisingly, his election of Aphrodite as the fairest Goddess infuriates the losing candidates: Juno, most notably, swears 'revenge ... on his progenye' (1. 534), and promises that Paris 'shall rue, and ban the dismay day' he made the unfortunate selection (531). ${ }^{22}$ In the play's subplot, Venus invents a 'strange revenge' to punish the coy, disdainful Thestylis: after a divine enchantment, the shepherdess falls madly for a 'foule croked Churle' who in turn 'crabedly refuzeth her' (669; 723-4). A divine quarrel also frames The Rare Triumphs of Love and Fortune (1582), a distant precursor to both Cymbeline and The Tempest. When the conflict between Venus and Fortune spills into the moral world, the unfortunate human pawns become entangled in a number of competing revenge plots: Prince 
Armenio, for example, pursues a blood feud against his sister's (ostensibly) low-born lover, while the wrongly banished Bomelio employs the dark arts in the name of his 'iust reuenge' (1. 873). ${ }^{23}$ Finally, Munday's Italianate romance Fedele and Fortunio (1584) depicts a group of suitors who routinely resort to declarations of revenge in their attempts to win the beautiful Victoria. Fedele, for example, vows that he 'will not rest before [he] be revengèd' upon rival Fortunio, while later in the play Fortunio himself elaborately ponders how to best avenge his beloved's infidelity (2.4.59). ${ }^{24}$ As such early plays demonstrate - and as the era's subsequent comedies confirmed - the rhetoric of revenge was ready grist for a variety of comic situations.

John Lyly, for example, was especially adept at deploying revenge motifs in his comic works. At the core of Endymion (1588), his best known play, the rebuffed Tellus vows to spoil her beloved Endymion's unlikely pursuit of the goddess Cynthia; her opening tirade splendidly unites the themes of love and revenge:

Treacherous and most perjured Endymion, is Cynthia the sweetness of thy life and the bitterness of my death? What revenge may be devised so full of shame as my thoughts are replenished with malice? Tell me ... if falseness in love can possibly be punished with extremity of hate. As long as sword, fire, or poison may be hired, no traitor to my love shall live unrevenged. $(1.2 .1-7)^{25}$

In Love's Metamorphosis (1588-90), a mythopastoral comedy that recalls both Peele's Arraignment and The Rare Triumphs, characters variously suffer the divine revenge of Ceres and Cupid. After her beloved disciple is assaulted, Ceres orchestrates a quick reprisal: 'as speedy shall be my revenge as thy rigor barbarous', she promises the attacker, before ravaging his lands with a heavensent famine (293). ${ }^{26}$ In the counterplot, a band of love-struck foresters seek vengeance against Ceres' nymphs, who are themselves punished by Cupid for their stubborn chastity. (The play achieves a comic resolution when the divine figures reconcile and revoke their acts of vengeance.) Finally, revenge is also featured in the comic subplot of Midas (1589), in which a group of cozened servants swear revenge against the barber Motto: they trick him into declaring 'the King's are ass's ears', a phrase deemed treasonous in the royal court (5.2.157). ${ }^{27}$

Other contemporary comedies embraced the revenge theme with even greater enthusiasm, underscoring the wide versatility of comic vengeance. A contest of wills between Comedy and Envy frames the pastoral tragicomedy 
Mucedorus (c 1590); when mirth eventually wins the day, Envy promises in the epilogue that 'A double reuenge another time ile haue' (14). ${ }^{28}$ More importantly, revenge is also central to the action of the play itself: having been displaced at court by the recent arrival of Mucedorus, the treacherous Segasto hires Captain Tremelio to 'find som meanes to work the shepherdes death'(2.2.80). After killing Tremelio in self-defense, Mucedorus offers a telling statement on the reciprocity of violence: 'To daie I liue reuenged on my foe, / To morrow I die, my foe reuenged on me' (2.2.138-9). In a widely contrasting comic context, revenge is equally crucial to $A$ Knack to Know a Knave (1592), in which both strands of a dual-comedic plot are punctuated by acts of vengeance. In the main action, King Edgar of England recruits his trusted courtier Ethenwald to woo a beautiful maid on his behalf; he is forced to swear vengeance, however, when his agent secretly betroths himself to the girl. The play's subplot, which has an interesting affinity with conventions of the later revenge play, sees the disguised (abstraction) 'Honesty' sniff out and elaborately punish a group of villainous brothers; their equally villainous father laments on his deathbed that 'Revenge stands with an iron whip, / And cries, Repent, or I will punish thee' (520). ${ }^{29}$ Though in the context of city comedy, the corrective figure Honesty is aligned with this vision of revenge; the four brothers are themselves finally sentenced to horrible deaths.

Though revenge did not always occupy such a central role, its thematic influence can nonetheless be detected widely throughout the era's extant comedies. In the anonymous Fair Em (1589-91), miscommunication and misdirection inflame 'reuenging wrath' among several sets of rival suitors: Mountey and Valingford, for example, nearly fight to the death before realizing they were both duped by the mutually beloved Em, while the King of Denmark vows that he will 'reuenge ... throughly' his daughter's elopement with William the Conqueror (1. 993). ${ }^{30}$ In John a Kent and John a Cumber (1587-90), two ladies plan to 'reuendgefully' kill both themselves and their husbands in order to escape an arranged marriage; their plan is forestalled, however, when the magician John a Kent happily spoils the nuptials (1. 462). ${ }^{31}$ Similarly, in Greene's magician comedy Frier Bacon and Frier Bungay (1589), Prince Edward must resist the urge to 'imbrace reuenge' against the trusted companion who wooed away his love (1. 1032). ${ }^{32}$ In the class-bending farce George a Greene, the Pinner of Wakefield (1587-92), a group of humiliated nobles seek revenge by murdering the lowly pinner George; in Wilson's similarly farcical The Cobbler's Prophecy (1587-93), Mars swears that his revenge will 'fill the world with bloodshed and with rage' after learning of Venus' adultery 
(D4v). ${ }^{33}$ As such examples suggest, the spirit of revenge was native to Elizabethan comedy, well before the development of revenge tragedy proper.

\section{Revenge and History}

Not surprisingly, revenge was an important motif in the early Elizabethan history play. Nonetheless, the extent of its prominence has perhaps been underestimated; in fact, virtually every extant specimen of the genre deploys revenge in some thematic or rhetorical capacity.

A series of early pseudo-history plays embeds revenge themes into the legendary depiction of ancient Britain. Vengeance is perhaps the central impulse of the anonymous Tragedy of Locrine (1585-91), a play that with its bloody, pseudo-Senecan rhetoric outdoes even many revenge tragedies. ${ }^{34}$ Locrine's response to his brother's death typifies the play's treatment of the theme:

For this revenge, for this sweet word, revenge

Must ease and cease thy wrongful injuries;

And by the sword of bloody Mars I swear,

Ne're shall sweet quiet enter this my front,

Till I be 'vengèd on his traitorous head

That slew my noble brother Albanact.

As the conflict between the British Trojans and Scythians intensifies, no less than four of the play's major characters embrace revenge vows, and in two separate incidents ghosts appear on stage demanding 'revenge for blood' (3.7.41). Similarly, the conventions and rhetoric of revenge underpin Hughes's The Misfortunes of Arthur (1588), a treatment of King Arthur's legendary death; in an obvious nod to Thyestes, the play opens with a vengeance-hungry ghost eager to ' $[\mathrm{g}]$ lutte on reuenge' (1. 9). ${ }^{35}$ Finally, the infamous love test in The Chronicle History of King Leir (c. 1590) allows Gonorill and Ragan to enact an 'unperceiv'd' vengeance against hated sister Cordella - 'our revenge', they gloat, '[s] hall be accounted piety in us' (1.2.74-6) - while later in the play, the king of Cambria embarks on an unsuccessful mission 'to prosecute revenge' against Cordella's husband (5.2.108). ${ }^{36}$

Revenge is similarly invoked in the era's more familiar chronicle history plays. Readers of Shakespeare's early histories regularly encounter the theme; it is a recurring motif in the Henry VI cycle (1588-92), and Richard III (15913) has well-documented atmospheric and structural debts to Seneca. ${ }^{37}$ (The 
earlier True Tragedy of Richard the Third [1585-90] is even more explicit in its Senecanism; in the play's second line, a blood-thirsty ghost cries 'vendicta'. ${ }^{38}$ ) In Edmund Ironside (1588-90), a battlefield reconciliation between two warring kings ruins the plans of Edricus, the Machiavel figure; after calling for 'Blood, death and vengeance', he swears in the play's last line that 'by heaven I'll be revenged on both of you' $(1.2051 ; 2061) .{ }^{39}$ Revenge also punctuates The Troublesome Reign of King John (1587-91): when the widow Constance is abandoned by her French allies, her 'wounded soul implores revenge' (4.208); similarly, the Bastard feels 'A thousand furies kindle with revenge' at the sight of an enemy wearing his father Richard I's famed lion skin (2.138). ${ }^{40}$ The Life and Death of Jack Straw (1590-3) begins when a group of discontented peasants vow to 'revenge [the] villainy' of King Richard II's excessive taxation (381). ${ }^{41}$ A revenge oath also initiates the action of Peele's romance-history Edward I (1590-1): after losing his beloved Elinor to the new English king, Prince Llullen of Wales swears to avenge his injury with the 'bloud of thousands guiltlesse' (1. 620). ${ }^{42}$ And finally, though a history play in name only, Greene's Scottish History of James IV (1590-1) embeds the spirit of revenge within the context of a romance narrative. After commissioning the murder of his inconvenient wife Dorothea, the adulterous King James envisions her 'ghost / Howling revenge for [his] accurséd hate' (5.6.31-2); in response, Dorothea's furious father (the King of England) wages a 'revenging war' against Scotland (5.3.26). ${ }^{43}$ The parties finally reconcile when, in romance fashion, Dorothea is revealed to be alive.

\section{Cross-Genre Revenge}

Finally, revenge was vital to a number of other dramatic genres, many of which had broad affinity with the English chronicle histories discussed above. Vengeance had a remarkable life in the so-called hero play, a dramatic form jump-started by the success of Marlowe's Tamburlaine (c. 1587); unsurprisingly, revenge was naturally suited to a genre dedicated to the thunderous exploits of emperors and tyrants. Marlowe himself was no stranger to revenge themes; in addition to the obvious motifs in The Jew of Malta (1589-90) and Edward II (1592), the rhetoric of revenge also gives shape to rivalrous love in Dido, Queen of Carthage (1585-7) and to the horrors depicted in The Massacre at Paris (1592-3). ${ }^{44}$ His imitators followed suit, and revenge soon became a staple of the Elizabethan hero play. Peele's The Battle of Alcazar (1588), which enacts the disastrous conflict responsible for crippling the contemporary 
Portuguese monarchy, employs a familial revenge motif: it contains many of the usual ornaments, such as ghosts crying vindicta, descriptions of hellish tortures, and prophecies of how 'gods shall pour down showers of sharp revenge' (1.1.88). ${ }^{45}$ In Greene's Alphonsus (c. 1588), the exiled Alphonsus burns to avenge the usurpation of his family's Aragonese dynasty; this main action is complimented throughout by a variety of minor revenge strands, such as that of the jilted queen Fausta. And demanding particular mention is the gruesome Selimus (1588-90), in which a framework of revenge exposes the dangers of uncertain succession and culminates in a remarkable body count. A representative example suggests the play's treatment of horror and revenge: in one instance, an unfortunate messenger is returned to his aged master blinded and dismembered, along with the threat that the perpetrator will also 'tear the old man piecemeal with [his] teeth / And color [his] strong hands with his gore-blood' (14.36-37). ${ }^{46}$ The authors (probably Greene and a collaborator) leave little doubt about the drama's selling-point: if the play is well received, they promise in the epilogue that 'The second part shall greater murthers tell' (7).

Revenge is particularly crucial to Greene's hero-romance Orlando Furioso (1591-2). In the opening scene, a host of foreign princes vie for the hand of Angelica, heir to the African empire; the rebuffed suitors, dishonoured by Angelica's selection of the lesser-born Orlando, swear to enact vengeance by waging war against her father. (The Machiavel Sacripant, who intends to pluck both Angelica and the crown from the weakened victor, gleefully commands 'sweet Reuenge' to 'incense their angrie mindes" [1.1.243].) ${ }^{47}$ When Sacripant's own suit is rejected, he moves to 'quittance all [his] ills' by framing Angela as an adulteress: her furious father, after hearing the report, vows ironically that 'Theseus in his rage / Did neuer more reuenge his wrongd Hyppolitus / Than I will on the false Angelica' (2.1.499, 732-4). Finally, Orlando swears vengeance on the treacherous Sacripant, whom he eventually kills in single combat. Orlando Furioso is an ideal example of what could usefully be termed a non-Kydian revenge play. Though it shares little of Kyd's precise formulations and conventions, it nonetheless employs the notion of revenge as a central organizing principle.

A related genre to the hero-play is the classical history play, another form that exploited the thematic potential of revenge. Though few early Elizabethan examples survive, the form apparently enjoyed great popularity; in the early 1580s, lost plays treated The Four Sons of Fabius (1580), Scipio Africanus (1580), and Caesar and Pompey (1582), to name only a sample. ${ }^{48}$ Extant 
specimens liberally invoke motifs of blood and vengeance, and it seems reasonable to suspect that gory revenge may have been a common feature of the genre. In The Wars of Cyrus (1588), for example, the conflict between King Cyrus of Persia and King Antiochus of Assyria is characterized by a series of competing revenge claims. In order to pursue revenge against Antiochus - the 'archtyrant murderer of [his] sonne' (1. 262) — the Assyrian lord Gobryas begins the play by defecting to the Persian army; for his part, Antiochus attempts to repay this betrayal by seeking 'reuenge vpon his daughters life' (638). ${ }^{49}$ Antiochus also seeks to avenge his own father, recently killed in battle with the Persians, through the assassination of Cyrus. Similarly, revenge punctuates key moments in Lodge's The Wounds of Civil War (1585-91): after assuming power early in the play, for example, the victorious general Scilla is said to swing a 'rash revenging hammer' when ruthlessly executing his former political adversaries (2.1.84). ${ }^{50}$

Finally, revenge is also crucial to the few extant biblical plays of the era. ${ }^{51}$ In Greene and Lodge's cautionary tale A Looking Glasse for London and England (1590), God threatens apocalyptic vengeance against the wicked city of Ninevah; as an angel warns, God's pending judgment is a horrible 'reuenge, armed with mightie plagues, / To punish all that liue in Niniuie' (ll. 174344). ${ }^{52}$ The purifying flames of heavenly justice are implicitly contrasted with the base vindictiveness of Ninevah's inhabitants: a spurned mother, for example, vows to her (admittedly treacherous) son that her 'curses shall haunt thy hatefull head, / And being dead, my ghost shall thee pursue' (1096-7). And though it almost certainly postdates The Spanish Tragedy, more traditional revenge tropes form the core of Peele's David and Bethsebe (1593-4). In the opening sequence, Absalom adopts a Machiavellian guise when avenging the incestuous rape of his sister Thamar: after learning of the crime, he promises to 'hunt occasion with a secret hate, / To worke false Ammon an ungracious end' (ll. 360-61). ${ }^{53}$ (Despite David's command, 'revenge not thou this sin' [394], Absalom eventually stabs his brother amidst a shepherds' feast.) Elsewhere in the play, King David is cursed by his enemy Semei in the typical language of Senecan horror:

O that the soules of Isboseth and Abner,

Which thou sentst swimming to their graves in bloud,

With wounds fresh bleeding, gasping for reuenge,

Were here to execute my burning hate: 
But I will hunt thy foot with curses still, Hence Monster, Murtherer, Mirror of Contempt.

Give the obvious thematic potential of exploring revenge in a biblical context, it seems safe to assume that the now lost plays similarly invoked the theme.

When, in 1591, Robert Wilmont revised the old Gismond of Salerne 'according to the decorum of these daises', he invented for his Tancred and Gismunda several new, bloody spectacles, including Tancred's on-stage blinding and suicide. ${ }^{54}$ Though very plausibly, of course, his morbid, vengeful play was designed to capitalize on The Spanish Tragedy or Titus Andronicus, one thing is certain: it owed little debt to the genre of revenge tragedy as is usually conceived, which did not flower until the late 1590s.

As I have attempted to demonstrate in this essay, revenge was a narrative and thematic element of the utmost importance to early Elizabethan theatre, much earlier than is usually recognized. Well before it found expression in the pen of Kyd, it was flexibly deployed throughout the period's early comedies, romances, histories, and hero-plays. Accordingly, when considering the larger historical trajectory of revenge tragedy's development, scholars must be careful not to underestimate the prominence of dramatic revenge before the advent of The Spanish Tragedy, the genre's inaugural offering. Vengeance enjoyed both rhetorical and narrative prominence on the early Elizabethan stage, and systematic survey reveals that a flexible discourse of revenge may be detected in a remarkably high number of pre-Kydian plays. From within this diffuse thematic context, Kyd systematized, intensified, and refined the dramatic use of revenge - and in doing so, gave birth to the genre now recognized as 'revenge tragedy'. The surviving corpus of early Elizabethan drama reveals that revenge must indeed stand with love and ambition as one of the most widely invoked themes of the period's earlier theatre - it did not merely ride to popular prominence on the back of Kyd's success. Accordingly, I hope that this survey will bring to light a crucial new category of evidence for the study of both revenge tragedy and revenge more broadly. As scholars continue to assess the literary and cultural significance of early modern revenge, this corpus of early Elizabethan drama must be seen as crucial grist for analysis. 


\section{Notes}

I would like to thank Frank Whigham, Wayne A. Rebhorn, Marjorie Curry Woods, Douglas Bruster, and the editors and staff of Early Theatre (including my anonymous readers) for their assistance with the preparation of this essay.

1 Ronald Broude, 'Vindicta Filia Temporis: Three English Forerunners of the Elizabethan Revenge Play', JEGP 72 (1973), 489. Subsequent quotes from Broude are also on 489.

2 Thomas Rist, Revenge Tragedy and the Drama of Commemoration in Reforming England (Burlington, 2008).

3 Notable exceptions, besides Broude's essay, include Eleanor Proser, Hamlet and Revenge (Stanford, 1977); Julia Dietrich, 'Justice in This World: The Background of the Revenger in the English Morality Drama', Journal of Medieval and Renaissance Studies 12 (1982): 99-111; the appendix to Peter Mercer, Hamlet and the Acting of Revenge (London, 1987); and the brief section on precursors to revenge tragedy in Lukas Erne's Beyond 'The Spanish Tragedy': A Study of the Works of Thomas Kyd (New York, 2001). Fredson Bowers's Elizabethan Revenge Tragedy, 1587-1642 (Princeton, 1940), the classic account of the genre, is also relatively inclusive.

4 This manner of wide inquiry has been advocated generally by Douglas Bruster in Shakespeare and the Question of Culture: Early Modern Literature and the Cultural Turn (New York, 2003).

5 In addition to Bowers, Elizabethan Revenge Tragedy, see Charles A. Hallett and Elaine S. Hallett, The Revenger's Madness: A Study of Revenge Tragedy Motifs (Lincoln, 1980) for a discussion of the typical tropes of the revenge tradition. Broude's list of 'classic' revenge tragedies includes, besides The Spanish Tragedy, plays such as Titus Andronicus, Hamlet, Antonio's Revenge, and The Revenge of Bussy D'Ambois ('Vindicta Filia Temporis', 500).

6 For a discussion of the play's possible dates, see the introduction to Philip Edwards's Revels edition of The Spanish Tragedy (London, 1959). More recently, Frank R. Ardolino has argued that the play celebrates England's victory over the Armada, while Lukas Erne posits a pre-Armada date. See Ardolino, Apocalypse \& Armada in Kyd's Spanish Tragedy (Kirksville, mo, 1995) and Erne, Beyond 'The Spanish Tragedy'.

7 In assessing the probable composition dates of the plays themselves, I have supplemented the basic data in Harbage's Annals of English Drama with critical editions in order to arrive at a rough scholarly consensus; the dates supplied, it follows, are tentative, and are only meant to serve as a broad reference. See Alfred Harbage et al., Annals of English Drama, 975-1700, Third Edition (London, 1989). (I have also 
consulted Gabriel Egan's 'Non-Shakespearean Drama Database', available at <http:// www.gabrielegan.com/nsdd/index.htm>).

8 Contemporaries had, of course, already begun to recognize certain conventions of revenge tragedy; Nashe's famous lampoon of Senecanism in the preface to Greene's Menaphon (1589) is one obvious example. However, with the exceptions of the UrHamlet and Titus Andronicus, the first true burst of revenge tragedy appeared at the end of the decade, with such plays as Antonio's Revenge (1600), Hamlet (1600), and Hoffman (1603). See The Works of Thomas Nashe, ed. Ronald B. McKerrow, 5 vols (Oxford, 1958), 3.315-16.

9 For the classic account of Seneca in the Renaissance, see Gordon Braden, Renaissance Tragedy and the Senecan Tradition: Anger's Privilege (New Haven, 1985). See also Bruce R. Smith, 'Toward the Rediscovery of Tragedy: Productions of Seneca's Plays on the English Renaissance Stage', Renaissance Drama 9 (1978), 3-37; Howard B. Norland, 'Adapting to the Times: Expansion and Interpolation in the Elizabethan Translations of Seneca', Classical and Modern Literature 16 (1996), 241-63; and Jessica Winston, 'Seneca in Early Elizabethan England', Renaissance Quarterly 59 (2006), 29-58.

10 Norland, 'Adapting to the Times', 247.

11 Thomas Norton and Thomas Sackville, Gorboduc; or, Ferrex and Porrex, ed. Irby B. Cauthen, Jr. (Lincoln, 1970).

12 Jocasta, in A Hundreth Sundrie Flowres, ed. G. W. Pigman iii (Oxford, 2000).

13 Gismond of Salerne, in Early English Classical Tragedies, ed. John W. Cunliffe (Oxford, 1912). For a discussion of the play's literary heritage, see Cunliffe, 'Gismond of Salerne', PMLA 21 (1906), 435-61.

14 Supposes, in A Hundreth Sundrie Flowres.

15 Damon and Pithias, in The Dramatic Writings of Richard Edwards, Thomas Norton, and Thomas Sackville, ed. John S. Farmer (New York, 1966).

16 Clyomon and Clamydes: A Critical Edition, ed. Betty J. Littleton (The Hague, 1968).

17 Robert S. Knapp, 'Horestes: The Uses of Revenge', ELH 40 (1973), 205.

18 For the play's connection to other contemporary treatments of the Agamemnon story, see Karen Maxwell Merritt, 'The Source of John Pikeryng's Horestes', RES 23.91 (1972), 255-66.

19 Horestes, in Three Tudor Classical Interludes: Thersites, Jacke Jugeler, Horestes, ed. Marie Axton (Totowa, NJ, 1982).

20 The precise social function of revenge on the early comic stage is a topic that especially demands further investigation. As Edward Muir has demonstrated, the vengeful spirit that so often animated early modern ritual had both a violent and a comic form - but crucially the boundaries between these forms were hardly distinct, and a carnivalesque context could regularly birth 'a continuum of behavior that makes it 
impossible to distinguish precisely between rituals that merely poked fun and those that led to killing' (Ritual in Early Modern Europe [Cambridge, 1997], 104). The rhetoric of revenge that so often appears in the era's comedies thus reflects, and perhaps channels, the deep-rooted operation of corrective social rituals. On comic revenge, see also Linda Anderson, A Kind of Wild Justice: Revenge in Shakespeare's Comedies (Newark, 1987) and G. Beiner, Shakespeare's Agonistic Comedy: Poetics, Analysis, Criticism (Cranbury, NJ, 1993).

21 The induction to $A$ Warning for Fair Women mocks the typical revenge play's 'filthie whining ghost, / Lapt in some fowle sheete' (1. 54-55). See A Warning for Fair Women: A Critical Edition ed. Charles Dale Cannon (Paris, 1975). The date of this play is unclear; though it was printed in 1599, scholars are uncertain how early it appeared. Similarly, Eastward Ho liberally mocks both The Spanish Tragedy and Hamlet; see Richard Horwich, 'Hamlet and Eastward Ho', SEL 11 (Spring 1971), 223-33.

22 The Araygnement of Paris, ed. R. Mark Benbow, in The Life and Works of George Peele, gen. ed. Charles Tyler Prouty, 3 vols (New Haven, 1952-70), vol. 3.

23 An Edition of the Rare Triumphs of Love and Fortune, ed. John Isaac Owen (New York, 1979).

24 A Critical Edition of Anthony Munday's Fedele and Fortunio, ed. Richard Hosley (New York, 1981).

25 Endymion, ed. David Bevington (Manchester, 1997).

26 Love's Metamorphosis in The Plays of John Lyly, ed. Carter A. Daniel (Lewisburg, 1988).

27 Galatea and Midas, ed. George K. Hunter and David Bevington (Manchester 2000).

28 Mucedorus in The Shakespeare Apocrypha, ed. C.F. Tucker Brooke (Oxford, 1918).

29 A Knack to Know a Knave, in Dodsley's A Select Collection of Old English Plays, rev. W. Carew Hazlitt, 15 vols (New York, 1874-76), vol. 6. Disguise plots are particularly common in the Jacobean revenge tradition. See David J. Houser, 'Purging the Commonwealth: Marston's Disguised Dukes and A Knack to Know a Knave', PMLA 89 (1974), 993-1006.

30 Fair Em (Malone Society Reprint), ed. W.W. Greg (Oxford, 1927).

31 John a Kent and John a Cumber (Malone Society Reprint), ed. Muriel St. Clare Byrne (Oxford, 1923).

32 Frier Bacon and Frier Bungay, in The Plays \& Poems of Robert Greene, ed. J. Churton Collins, 2 vols (Oxford, 1905), vol. 2.

33 Thomas Wilson, The coblers prophesie (London, 1594; sTC 25781).

34 The Lamentable Tragedy of Locrine: A Critical Edition, ed. Jane Lytton Gooch (New York, 1981). 
35 The Misfortunes of Arthur, in Cunliffe, Early English Classical Tragedies. For a discussion of Seneca's influence on the play, see William A. Armstrong, 'Elizabethan Themes in The Misfortunes of Arthur', RES 7.27 (1956): 238-49.

36 The Chronicle History of King Leir: The Original of Shakespeare's 'King Lear', ed. Sidney Lee (London, 1909).

37 See, for example, Robert S. Miola, Shakespeare and Classical Tragedy: The Influence of Seneca (Oxford, 1992).

38 The True Tragedy of Richard the Third, ed. Barron Field (London, 1844).

39 Shakespeare's Lost Play, Edmund Ironside, ed. Eric Sams (New York, 1985).

40 The Troublesome Reign of King John: Being the Original of Shakespeare's Life and Death of King John, ed. F.J. Furnivall and John Munro (London, 1913) [Part One].

41 The Life and Death of Jack Straw, in A Select Collection of Old English Plays, vol. 5.

42 Edward I, ed. Frank S. Hook, in Peele, Life and Works, vol. 2.

43 Robert Greene, The Scottish History of James the Fourth, ed. Norman Sanders (London, 1970).

44 For example: Iarbas, the jilted suitor of Dido, seeks vengeance in the murder of rival Aeneas (3.3.70-85), while in the Massacre the assassination and mutilation of Admiral de Coligny is celebrated as a 'just revenge' (5.44). Both plays are available in 'Dido, Queen of Carthage', and 'The Massacre at Paris', ed. H. J. Oliver (Cambridge, MA, 1968).

45 The Battle of Alcazar, in The Stukeley Plays, ed. Charles Edelman (Manchester, 2005).

46 Selimus, in Three Turk Plays from Early Modern England: Selimus, A Christian Turned Turk, and the Renegado, ed. Daniel J. Vitkus (New York, 2000).

47 Orlando Furioso, in The Plays \& Poems of Robert Greene, vol. 1.

48 See Gertrude Marian Sibley, The Lost Plays and Masques, 1500-1642 (Ithaca, 1933).

49 The Wars of Cyrus: An Early Classical Narrative Drama of the Child Actors: Critical Edition with Introduction and Notes, ed. James Paul Brawner (Urbana, IL, 1942).

50 Thomas Lodge, The Wounds of Civil War, ed. Joseph W. Houppert (Lincoln, 1969).

51 Beside the interludes and moralities of the 1560s, few biblical dramas survive. Annaliese Connolly notes that only two of the thirteen probable specimens from the 'long 1590s' are extant. (The two plays referenced in this paragraph). See Annaliese Connolly, 'Peele's David and Bethsabe: Reconsidering Biblical Drama of the Long 1590s', Early Modern Literary Studies Special Issue 16 (October 2007), <http://purl. oclc.org/emls/si-16/connpeel.htm>.

52 A Looking Glasse for London and England, in The Plays \& Poems of Robert Greene, vol. 1.

53 David and Bethesbe, ed. Elmer Blistein, in Peele, Life and Works, vol. 3. 
I34 BRADLEY J. IRISH

54 For discussion of the relationship between Gismond of Salerne and Tancred and Gismunda, see David Klein, “'According to the Decorum of These Daies", PMLA 33 (1918), 244-68; John Murray, 'Tancred and Gismund', RES 14.56 (1938), 385-95; and Kyoko Iriye, 'A Stylistic Comparison of Gismond of Salerne and Tancred and Gismund, Shakespeare Studies [Tokyo] 4 (1966), 1-35. 